\title{
Reforming Urban Governance in India: A Contemporary Perspective
}

\author{
Dr. Ruchi Chowdhary ${ }^{1} \quad$ Anjna Kumari ${ }^{2}$ \\ 1.Assistant Prof. Dept. of Public Policy and Public Administration, Central University of Jammu \\ 2.Research Scholar, Dept. Of Public Policy and Public Administration, Central University of Jammu
}

\begin{abstract}
Introduction Urbanization worldwide has been found to be an effective engine of economic growth and sociocultural development. In pure economic terms, urbanization contributes significantly to the national economy. The pace and growth of urbanization in India poses enormous challenges to urban governance. This article examines the institutional features and devolution mechanisms of the federal framework within which cities have to deliver better quality of life for their residents and generate an investment climate that is capable of sustaining the rapid growth. It argues that though planned urbanization is needed for the industry and services sectors and also for rural rejuvenation, the lack of empowerment of cities is constraining their ability to translate the urban development agenda into action. The article emphasizes the importance of bridging the urban infrastructure deficit and argues that institutional reforms are crucial for reaching out to the private sector for sharing the financing burden and ensuring that it results in improved service delivery.
\end{abstract}

Keywords: Urban governance, infrastructure, service delivery, Institutionalize.

DOI: $10.7176 / \mathrm{JAAS} / 54-02$

Publication date: April $30^{\text {th }} 2019$

\section{Introduction}

It is well known that urbanization and economic growth are interlinked as cities provide economies of agglomeration, and, in India, too the impetus for growth is envisaged to come from the urban sector. Currently, cities accommodate 377 million i.e. $31 \%$ of India's current population and contribute $63 \%$ of the GDP and are expected to accommodate 800 million in 2050, when one out of every two Indians would be living in urban areas. However, this rapid urbanization is putting pressure on available infrastructure facilities like water, sanitation, housing, schools, hospitals, colleges and mobility etc. in the urban areas. The provisioning of adequate infrastructure requires huge finances. A look at the urban local finances in India indicates that most of the ULBs are lacking in mobilization of resources and financial autonomy. The total revenues of all Urban Local Bodies (ULBs) in India amount to less than Rs. 1, 50,000 crores, approximately, 1\% of India's GDP. The deficiency of infrastructure affects the city's ability to attract investment. The urban local bodies (ULBs) are the principal catalysts and efficacy of urbanization and economic growth would be impacted in the manner the functions are carried out and finances are mobilized.

India has been among the fastest growing economies in the world for close to 2 decades. Faster growth has obvious implications for the pace and nature of urbanization. The combination of rising aspirations and growing middle classes on the one hand and inadequate planning for the inevitable increase in urbanization on the other is creating a situation that is socially, financially, and environmentally unsustainable (Gore \& Gopakumar, 2015). The challenge facing India's planners and policymakers is how to radically improve the quality of life in cities so that they can continue to accommodate future growth while ensuring better living conditions for their residents and synergetic development of the rural sector. This article argues that reform in the institutions of urban governance is crucial in addressing this challenge. There are three overwhelming roadblocks to better urban governance in India: a federal framework that has not empowered its third tier despite amending the constitution in 1992 for doing so, a missing link in the institutional framework for metropolitan planning and governance, and a political system that is heavily biased toward the rural sector (see, e.g., Kazmin [2016] and the section "Anti-urban bias in the political regime," below). Unless institutional reforms are put in place to address these challenges effectively, the process of urbanization cannot be taken forward to support the twin objectives of improving the quality of life of India's rapidly growing urban population and transforming Indian cities to play their role as engines of growth in India's current stage of development (Corbridge, Harriss, \& Jeffrey, 2012).

While the Constitution of India envisaged a two-tier system of federation, the 74th Constitutional Amendment Act, 1992 added third tier of government viz. urban local bodies. The amendment aimed at devolution of functions, finances and functionaries to ULBs. Enormous responsibilities like preparation and implementation of plans for economic developments and social justice, etc., have been identified for ULBs in the Act, besides the 18 items of responsibilities envisaged in $12^{\text {th }}$ Schedule of the constitution as legitimate functions of Urban Local Bodies.As a result, accountability now rests with the urban local bodies but it is not backed by either adequate finances or the capacity for planning and management (a well-known problem; e.g., see Meloche \& Vaillancourt, 2015). State governments have an important role to play not only in transferring functions, funds, and 
functionaries but also in providing an enabling environment through legislative and institutional reform, whereas the Government of India can only provide strategic leadership.

The resource base of ULBs typically consists of their own sources, state revenue, government grant, loans from state governments, and market borrowings. The urban local bodies are sometimes not even aware of the opportunities and avenues of generating revenues through taxes and non-tax charges. Even if they are aware, they do not have the skill to optimize tax collection. ULBs in India, therefore, have a minimal revenue base and largely dependent on Central and State grants, which constrained the ability of ULBs to invest adequately in capital expenditure like creating infrastructure and, thereby, improve quality of life in the city.

AMRUT reforms are some of the steps taken by Government towards financial strengthening of these ULBs. The recent updates like 94 cities in 14 states of India receiving credit ratings from rating agencies such as Crisil; as part of the cities' preparations for issuing municipal bonds and Pune Municipal Corporation raised Rs. 200 crore by issuing 10-year municipal bonds are welcoming steps towards the financial empowerment of ULBs. CARE estimation that of Rs. 1,000- Rs. 1,500 Cr. per annum over the next five years would be raised by way of Municipal bonds is an indication of the expected growth in the market in the years to come.

Inadequate capacity at the local government level to respond to the challenges of urban planning and management in a rapidly evolving urban scenario is the other crucial challenge faced by Indian cities. Urban local bodies have come to acquire a host of functions that are new if not unprecedented. These include preparation of a city development plan, city mobility plan, city sanitation plan, e-governance, and meeting the numerous benchmarks set by the Government of India for service delivery. The experience of the 2005-2014 period under Jawaharlal Nehru National Urban Renewal Mission (JNNURM), a national mission for urban renewal and rejuvenation, clearly highlighted the lack of capacity at the urban local government level as a major constraint in planning and implementing the projects for urban development (see, e.g., Grant Thornton [2011] and the subsection on JNNURM later). State governments will have to develop and strengthen their municipal cadres and support their training in contemporary tools of urban planning and management, in financial management through accrual-based, double-entry financial bookkeeping and regular audits, and in use of egovernance tools. A major capacity-building program involving institutional support through schools of urban planning and management was recommended by the High Powered Expert Committee on Urban Infrastructure and Services (HPEC, 2011), which was set upby the Government of India in 2008 under the chairmanship of the present author to determine the investment requirements over a 20-year period, 2012-2031. Serious efforts at building capacity at the urban local government level will have to be made by the Government of India as well as state governments.

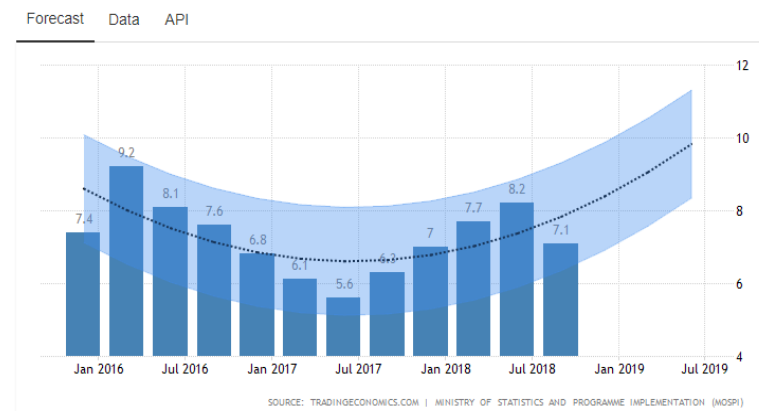

Figure 1. A snapshot of India's GDP growth. Source: Central Statistical Office, Ministry of Statistics Program and Implementation.

Rising urbanization Rapid growth is necessarily associated with an increase in the share of urban GDP. For India's rapid growth phase, such estimates are available for 1999-2000 and 2009-2010. They indicate that the share of urban GDP in the total has increased from 52\% in 1999-2000 to 63\% in 2009-2010 (Planning Commission, 2011). However, India's urbanization is much lower than that of most countries that are its natural comparators. In 2015, 33\% of India's population was urban, compared to 54\% in Indonesia, 56\% in China, $79 \%$ in Mexico, $83 \%$ in Korea, and $87 \%$ in Brazil (United Nations, 2014). There is reason to believe that the urban population share is underestimated in India (HPEC, 2011); the absolute numbers are staggering nevertheless. India is home to the second largest urban population in the world. Its urban population increased from 286 million in 2001 to 377 million in 2011; it was estimated at about 420 million in 2015 and is projected to increase to close to 600 million by 2031. As investments in industry and services look for urban space to garner economies of agglomeration, both market forces and the government have to play an important role in generating these economies. Because there was no integrated planning of transport and land use, investors faced congestion diseconomies and environmental degradation and in the process themselves contributed further to the 
deterioration in the standards of urban living. Planned urbanization is needed as much for the industry and services sectors as it is for rural rejuvenation because it fosters the synergy between rural and urban sectors. For example, the quantity and quality of water available for agriculture is significantly affected by water use in urban areas. Similarly, modernization of the retail sector in urban areas including foreign direct investment encourages investments in logistics and back-end infrastructure, offering opportunities for high-value agriculture. Punjab in the post-1991 period clearly shows that without an industrial policy and an urbanization strategy in place, a rich agricultural base cannot continue to deliver rapid economic growth. Punjab failed to invest in urban infrastructure to develop its cities as engines of growth, which would also have provided fillip to agricultural modernization. The result was that industrial growth was slow and agricultural growth also stagnated (Ahluwalia, Chaudhuri, \& Sidhu, 2008). From being the state with the highest per capita income until the late 1980s, Punjab was 15th among India's states and union territories in 2014-2015 (Central Statistical Office, 2015).

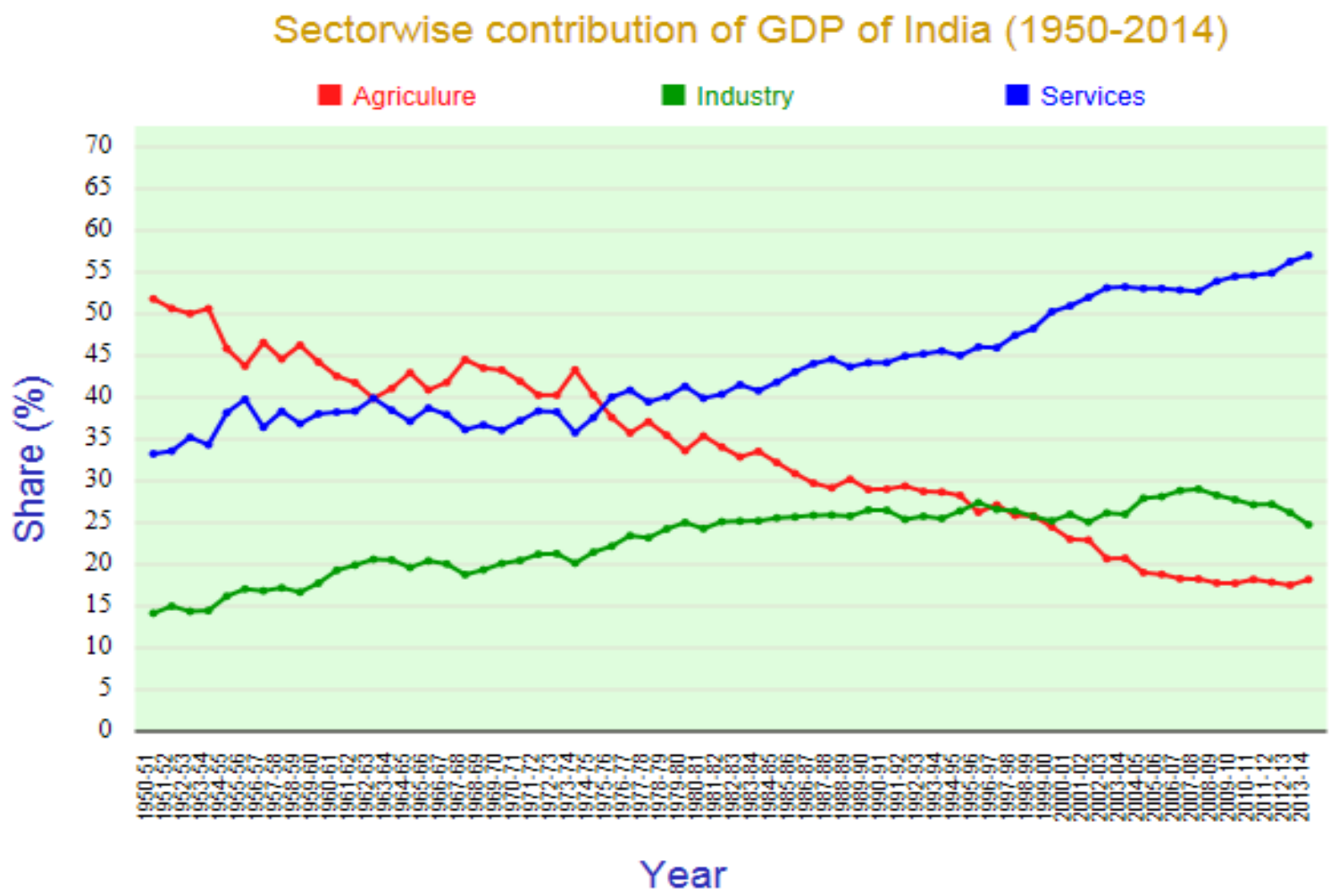

Figure 2. (a) Share of major sectors in GDP Source: Central Statistical Office, Government of India; NSSO Employment and Unemployment Survey, 61st and 68th rounds.

Creating employment and generating skills Expanding employment opportunities in the industry and services sectors to provide scope for highproductivity jobs in urban areas continues to be the principal challenge for India's policymakers. The share of agriculture in GDP has declined to less than $14 \%$, but almost $50 \%$ of the total employmentgenerated in the economy is still in agriculture (see Figure 2). Growth of employment did not keep pace with the growth of output in the non-agriculture sectors. This has serious implications for a growing pool of the unemployed in urban areas. Scarcity of skills emerged as a major challenge as the rapid growth of GDP showed how unprepared India was and still is with respect to the demand for skilled manpower. India's working-age population as a proportion of the total population will continue to rise until 2040, unlike that in China, where a decline began in 2010, and Brazil, where it will begin in 2020 (Figure 3). This demographic opportunity for India can be converted into a demographic dividend if the youth are empowered with the necessary skills and higher education.

\section{Infrastructure development: New challenges}

The inadequacy and poor quality of physical infrastructure-for example, roads, transport, electricity, and telecommunications - has been a longstanding major factor holding back Indian industry from attaining global competitiveness. Though breakthroughs in mobile telephony and the penetration of mobile phones in the Indian economy have revolutionized telecommunications, rapid growth of the economy has brought to light some gaping holes in basic physical infrastructure for industrial development, including that needed for planned urbanization.

Larger public investment in both general physical infrastructure for economic development and urban 
infrastructure will require purposefully cross-subsidizing where possible, targeting subsidies to the poor, and plugging leakages in order to find financial resources for public investment in infrastructure (Haldea, 2011). In recent years, with the opening of the infrastructure sector to private investment, there is a growing expectation of private finance supplementing public funds in the development of infrastructure for cities as well as for industrial development. Inadequate capacity for planning and negotiating at the urban local government level to enter into public private partnerships and inadequate support from state governments in creating an enabling environment are other reasons for private financing not coming forth.

Campaign (Swachh Bharat), Atal Mission for Rejuvenation and Urban Transformation (AMRUT), the Smart Cities Mission, and Housing for All, which are currently at different stages of planning and implementation. In a federal framework, the challenges in the implementation of the national missions arise both from the resistance on the part of state governments to devolve functions, finance, and power to the local governments and from weak local government capacity to plan and manage new projects and programs. Because the metropolitan regions are becoming increasingly more important in the economic geography of India in its current stage of development, the missing middle of a functional metropolitan institutional framework poses an additional challenge for implementing projects with due regard for metropolitan and regional connectivity (Matkin \& Frederickson, 2009). An assessment of JNNURM is presented below with a view to highlighting the lessons that must be incorporated in the design and implementation of the new urban missions.

Jawaharlal Nehru National Urban Renewal Mission (JNNURM) The JNNURM was launched by the Government of India in December 2005 in partnership with the state governments and urban local governments (JNNURM, 2011).11 The Government of India committed Rs 660 billion as its share in a total investment pool of over Rs 1 trillion. For the 65 mission cities, the urban local body was required to prepare a city development plan (CDP) and identify a specific infrastructure project for funding. The state government would approve both the CDP and the project, and the project would be taken to the Government of India for approval and part financing. The state government and urban local governments also made financial contributions. The investment support from the Government of India in installments was conditional on a set of reforms by the state government and the urban local governments. The design of the JNNURM made it very difficult to enforce the conditionality of reforms. It was politically difficult for the Government of India to withhold disbursements on a project that was being implemented well just because reforms were not carried out by the state and/or city governments. Because most city governments did not cross the threshold of reforms that would generate a credible revenue model, private finance did not come through. The expectation about leveraging limited government funds with substantial private financing for urban infrastructure investment therefore did not materialize. The funding remained limited to the amounts set aside by the Government of India and contributions from state Governments and urban local governments. By July 2014, Rs 521 billion was disbursed by the Government of India for urban infrastructure projects which had a total cost of Rs 1.292 trillion. More than 50\% of the amount was disbursed for projects in water and sanitation (Ahluwalia, 2016). JNNURM served as a catalyst for the urban sector, which had for long been starved of funds since the urban local governments were financially much too weak to make the necessary investments in infrastructure (Sivaramakrishnan, 2011). It generated a lot of action on the ground; for example, preparing CDPs, identifying and proposing infrastructure projects for funding, and joining in competitions sponsored by the Government of India for being recognized as best urban projects in different sectors. The state of Maharashtra even set up its own mini-mission on water and sanitation, Maharashtra Sujal Nirmal Abhiyan, supported by the World Bank, to nudge urban local governments to carry out reforms and receive funding for projects in the water and sanitation sector from the state government, which, however, was subsequently abandoned.12 The focus of JNNURM on bridging infrastructure deficit through project funding meant that the final link from infrastructure to improving service delivery was neglected. In addition, capacity for urban planning and management at the local government level to rise to the occasion proved to be a major challenge. Even though funds were set aside in the mission for capacity building, this aspect was neglected, with the result that the quality of the urban renewal effort suffered. Notwithstanding the multiple challenges of enforcing reforms and struggling with limited capacity for urban planning and management on the ground, JNNURM played a very important role in energizing urban local governments. Some examples of amazing transformations at the city levelemerged during this period. In Transforming our Cities (Ahluwalia, 2014b), the present author documented a number of case studies showing how Indian cities in some sectors were able to transform the state of service delivery within a very short period. For example, it took Malkapur, a small town with a population of 40,000, only 5 years (from 2008 to 2013) to provide continuous water supply from a treated source for all. Alandur, a town outside of Chennai with a population of 164,000, moved from zero underground sewerage networks in 2000 to complete coverage and treatment of sewage in 2005. Nagpur has taken an integrated approach to water by investing both in a piped network for distribution of drinking water and in treatment of wastewater. Surat has successfully responded to its major challenges of flooding through expansion of its drainage network and putting in place the infrastructure for wastewater treatment. More recently, Surat has prepared a city resilience strategy that is being implemented to ensure 
sustainable development.

New initiatives for urban renewal Following a 6-month hiatus after the end of JNNURM in April 2014, the Government of India announced a number of new initiatives directed at urban rejuvenation. The first of these was a broad-based Clean India (Swachh Bharat) campaign launched in October 2014 with an urban component. This was followed by the announcement in June 2015 of three major national urban missions: AMRUT, Housing for All by 2022, and Smart Cities Mission.

AMRUT is effectively the successor to JNNURM. It covers infrastructure for water, sewerage, drainage, transport, and green spaces in 500 cities with a total outlay of Rs 500 billion over a 5-year period (AMRUT, 2015). Unfortunately, municipal solid waste management is not in the ambit of AMRUT (but is part of Swachh Bharat), although an integrated and coordinated effort on solid waste management within the same programthat is, AMRUT - would be much better for addressing the challenges of sanitation. Another major weakness of AMRUT is that the urban improvement efforts of the mission are disconnected from any CDP. Though an urban local body is required to prepare a service-level improvement plan and a state annual action plan, the absence of the requirement to work within the framework of a CDP is a step backward even though the concept of CDP was much abused under JNNURM. As in the case of JNNURM, disbursements under AMRUT are linked to a set of reforms, although clarity is yet to emerge on exactly which reforms are to be

part of the conditionality. The challenge for AMRUT will lie in enforcing the conditionality of reforms, precisely where JNNURM failed. The Housing for All mission aims to create 20 million houses in the urban sector by 2022 (Government of India Cabinet, 2015).

With regard to private finance under public-private partnership, as mentioned earlier, the JNNURM experience clearly shows that private finance is attracted only if there is a revenue model that ensures a reasonable return on their investment. Moreover, capacity of urban local bodies needs to be strengthened for them to enter into public-private partnership in a transparent and accountable manner. There is also need for a clear and transparent assignment of risks for both partners and an effective dispute resolution mechanism if public-private partnerships are to play a supportive role in urban infrastructure investments and public service delivery. In the absence of basic reforms at the state and urban local government levels, public-private partnerships will not bring in complementary funds from the private sector.

A summing up The analysis in this article has highlighted the central importance of strengthening urban governance in India, especially in its current stage of development when the economy is going through a major structural transformation. It has argued that for India, as one of the largest and fastest growing economies in the world, and one in which urban population is only $33 \%$ of the total population but gathering momentum, planned urbanization is crucial for the sustainability of rapid growth and for improving the quality of life of the 420 million people living in Indian cities and towns.15 Though investing in urban infrastructure to bridge the infrastructure investment deficit and upgrading its quality is very important, the analysis clearly suggests that institutional reforms are crucial both for reaching out to the private sector for sharing the financing burden of infrastructure and for ensuring that the expansion of infrastructure results in improved service delivery. The article argues that Indian cities are not empowered to take on the enormous challenges of delivering public services and planning and managing the process of urbanization, which is inevitably associated with rapid economic growth. The opportunity provided by GST has not been used to ensure that a small proportion of the state government's share of GST is earmarked for transfer to local (rural and urban) governments. Guaranteed financial transfers, together with a degree of financial autonomy and building capacity for urban planning and management, will help the cause of empowerment of thecities. Inaddition, institutions of metropolitan and regional planning need to be strengthened to address the challenges arising from structural transformation of the economy (Matkin \& Frederickson, 2009).

\section{Way Forward}

Although, the Constitutional Amendment in 1992 paved way for greater devolution of power, functionaries and finances, the problems of devolution remains. The Urban Transformation Agenda necessitates the improvement of financial base of municipalities to facilitate provision of adequate basic services to the citizens along with strengthening of municipal cadre.

Strengthening capacities of ULBs is necessary for effective resource mobilization Currently their Financial capacity is restricted not only by low tax base but also low capacity for mobilization of existing resources. As per the available literature, the ULBs are not able to harness property tax as per their potential due to undervaluation; non-availability of database of properties; low rates; low collection efficiency and lack of indexation of property values.

Financial self-sufficiency of the ULBs is the need of the hour. This can be achieved through encouraging municipal bonds, review of property tax system to improve efficiency and transparency in collection and mobilization of resources. It is also necessary to evolve a time bound strategy to devolve the subjects mentioned under the $74^{\text {th }}$ Constitution Amendment Act, 1992. 
Financial sustainability necessitates adequate financial accountability requiring adhering to Fiscal Responsibility and Budget Management Act, 2003 (FRBMA) that provides for finances and borrowings to remain within manageable limits. Due importance needs to be accorded to Public accountability and transparency of revenues and their usage.

Further, need for Capacity building of Commissioners as to the importance of financial management, time bound preparation of financial statements for increase in efficiency. The improved Service Delivery is the cornerstone for effective and sustainable urbanisation. There is also a need to explore alternative sources of revenue generation by the municipalities such as entertainment tax, mobile towers, user charges for solid waste, water, parking, value capture financing, etc. In order to enhance citizen participation, e-governance tools like online procurement, tenders, and online expenditure reports, should be used.

Showcasing best practices from different states can also be replicated in other areas such as the success of Karnataka's Municipal Accounting and Budgeting Rules, 2006 (KMABR, 2006) and the formation of Karnataka Municipal Data Society (previously known as Municipal Reform Cell). This requires strong commitment from both Centre and State to empower the ULBs to improving their financial positions and efficient delivery of services and implementation of the Urban Transformation Agenda through a well-designed roadmap.

Theconstrainedpowersofcitiestomakedecisionsandthegenerallygreaterresponsivenessofthepolity to rural interests are not apparent only in India. Other (federal) polities have been known to have similar features (for the case of the United States, see Frug, 1999; Frug \& Barron, 2008). However, the pressures of growth in India make these institutional challenges more extreme. The national urban missions have raised great expectations. But as JNNURM showed, it is when state governments are proactive in coming forth with necessary legislative reforms, institutional framework for financial and regulatory support, financial devolution, and helping build capacity at the urban local government level that the impact can be seen in significant improvement in service delivery (Frug \& Barron, 2008). To the extent that these missions provide strategic focus on urban planning and management and succeed in nudging the state governments into action to decentralize, devolve, and build capacity at the urban local government level, they will make a difference. But the heavy lifting will have to be done by the states. The technology focus of the national missions seems to have caught the fancy of many. It is for this reason that the Smart Cities mission has attracted greater investment than Swachh Bharat. However, the technology focus must be supplemented with heavy emphasis on institutional reforms if Indian cities are to deliver a better quality of life and improve the investment climate for business.

\section{References}

Ahluwalia, I. J. (2014a). Improving our cities through better governance. London, England: LSE Cities.

Ahluwalia, I. J. (2016). Challenges of urbanisation in India. In T. Besley (Ed.), Contemporary issues in development economics (pp. 163-177). London, England: Palgrave Macmillan.

Ahluwalia, I. J., Chaudhuri, S., \& Sidhu, S. (2008). Punjab industrial review. Punjab, India: United Nations, Industrial Development Organization.

Ahluwalia, I. J., Kanbur, R., \& Mohanty, P. K. (2014). Urbanisation in India: Challenges, opportunities and the way forward. New Delhi, India: Sage India.

Ahluwalia, I. J., Munjee, N., Mor, N., Vijayanunni, M., Mankad, S., Lall, R., ..., Srivastava, P. K. (2011). Report on Indian urban infrastructure and services. New Delhi, India: Government of India, Ministry of Urban Development.

Burdett, R., Rode, P., Shankar, P., \& Vahidy, S. (2014). Governing urban futures. London, England: LSE Cities.

Central Statistical Office. (2016). Ministry of Statistics and Programme Implementation, Government of India.

Corbridge, S., Harriss, J., \& Jeffrey, C. (2012). India today: Economy, politics and society. Cambridge, England: Polity Press.

Frug, G. E. (1999). City making: Building communities without building walls. Princeton, NJ: Princeton University Press.

Frug, G. E., \& Barron, D. J. (2008). City bound: How states stifle urban innovation. Ithaca, NY: Cornell University Press.

Gore, C. D., \& Gopakumar, G. (2015). Infrastructure and metropolitan reorganization: An exploration of the relationship in Africa and India. Journal of Urban Affairs, 37, 548-567.

Grant Thornton. (2011). Appraisal of Jawaharlal Nehru National Urban Renewal Mission (JNNURM), New Delhi, India.

Haldea, G. (2011). Infrastructure at crossroads: The challenges of governance. New Delhi, India: Oxford University Press India.

Jagannathan, K. T. (2015). Recommendations of the 14th finance commission. The Hindu.

KPMG. (2014). Decoding housing for all by 2022. India: KPMG India and National Real Estate Development Council (NAREDCO).

Mathur, O. P., \& Peterson, G. (2006). State finance commissions and urban fiscal decentralization in India 
(Prepared for USAID by The Urban Institute). Washington, DC: The Urban Institute.

Matkin, D. S. T., \& Frederickson, H. G. (2009). Metropolitan governance: Institutional roles and interjurisdictional cooperation. Journal of Urban Affairs, 31, 45 -66.

Meloche, J. P., \& Vaillancourt, F. (2015). Designing proper fiscal arrangements for sub-local decentralization in Montreal. Journal of Urban Affairs, 37, 530-547.

Mohanty, P. K. (2016). Financing cities in India: Municipal reforms, fiscal accountability and urban infrastructure. New Delhi, India: Sage India.

Moonen, T., Moir, E., \& Clark, G. (2014). Underpowered cities. In R. Burdett, P. Rode, P. Shankar, \& S. Vahidy (Eds.), Governing urban futures (p. 15). London, England: LSE Cities.

Mukherjee, A. (2013). The service sector in India (Working Paper No. 352). Manila, Philippines: Asian Development Bank.

Panagariya, A. (2014). Space, services and the state. In R. Burdett, P. Rode, P. Shankar, \& S. Vahidy (Eds.), Governing urban futures (pp. 39-40). London, England: LSE Cities.

Patel, B., \& Phatak, V. K. (2014). Integrating redevelopment of slums in city planning. In I. J. Ahluwalia, R. Kanbur, \& P. K. Mohanty (Eds.), Urbanisation in India: Challenges, opportunities and the way forward (pp. 260-296). New Delhi, India: Sage India.

Planning Commission. (2011). Mid-term appraisal eleventh five year plan: 2007-2012. New Delhi, India: Oxford University Press India.

Raghuram, G., \& Sunny, S. (2015). Right to fair compensation and transparency in land acquisition, rehabilitation and resettlement ordinance 2014: A process perspective (Working Paper No. 2015-07-03). Ahmedabad, Gujarat, India: Indian Institute of Management.

Rangarajan, C. (2005). Reports of the finance commissions of India: First to the twelfth finance commission. New Delhi, India: Academic Foundation.

Rao, G., \& Bird, R. (2014). Governance and fiscal federalism. In I. J. Ahluwalia, R. Kanbur, \& P. K. Mohanty (Eds.), Urbanisation in India: Challenges, opportunities and the way forward (pp. 1-28). New Delhi, India: Sage India.

Roy, A. (2014). The land question. In R. Burdett, P. Rode, P. Shankar, \& S. Vahidy (Eds.), Governing urban futures (p. 13). London, England: LSE Cities.

Sivaramakrishnan, K. C. (2011). Re-visioning Indian cities: The urban renewal mission. New Delhi, India: Sage.

Sivaramakrishnan, K. C. (2015). Governance of megacities fractured thinking, fragmented setup. New Delhi, India: Oxford University Press.

United Nations. (2014). World urbanisation prospects: The 2014 revision. New York, NY: Department of Economic and Social Affairs, Population Division, United Nations.

Venables, A. J. (2009). Rethinking economic growth in a globalizing world: An economic geography lens (Working Paper No. 18). Washington, DC: Commission on Growth and Development, The World Bank.

World Bank. (2012). Lessons from business plans for Maharashtra, Rajasthan, Haryana and international good practices. Washington, DC 